Yusupov Saidvali,

Tashkent Institute of textile and light industry, senior lecturer, the Department of Management

E-mail: saidvaliyusupov@mail.ru

\title{
The innovative strategy of development of light industry of Uzbekistan
}

Abstract: this article considers the issues of innovative strategy of development of light industry of Uzbekistan. Key benchmark for further work is to increase the production of goods for the domestic market, to meet the growing needs of the population and increasing national importance of the industry and its image in the world community.

Keywords: Light industry, innovation, strategy, assortment, materials, quality, simulation, strategic objective, investment projects.

Introduction: Light industry is one of the strategic sectors in the economy of Uzbekistan. It promotes the increase of industrial production, increase of the export potential, to the harmonious development of the regions, employment of the population and improve their wellbeing, contributes to the establishment and development of small and private businesses.

Analysis: To date, a significant portion of textile and sewing and knitting industry is represented by enterprises of SJSC "Uzbek light industry", which was established in 2002 on the basis of the Uzbek state Association of light industry goods. In its composition the company has 308 companies and organizations, including in the textile industry 130 companies, sewing and knitting - 135, in the silk industry -36 and 7 commercial enterprises [6].

Over the last $10-15$ years in the global industrial practice has undergone radical changes in the technological processes of textile and light industry, allows to produce fundamentally new products that meet the demand of the consumers. Currently the production capacity of the enterprises of SJSC "Uzbek light industry" is estimated to amount to cotton yarn -410 thousand tons, cotton fabrics - 281.8 million $\mathrm{m}^{2}$, knitted fabrics -81.8 thousand tons, knitted products - 256 million units, hosiery products is 71.3 million pairs, the thread of raw silk 2.5 thousand tons [6].

The company also provide the needs of the market in products of wide range and assortment for special users, including produce health products, non-woven materials, needs for cotton products, special working clothes, Terry products, and ensure the development and introduction into production of a new generation of innovative new products [2].

In order to improve the organization of the development of popular modern models of clothes, taking into account national traditions and climatic conditions, as well as a wide product promotion of domestic textile

industry on the international markets created Unitary enterprise "Design center shark liblary".

The services provided by the Design center:

- implementation of advanced modeling of light industry products, to meet the growing needs of the population the study of the latest world fashion trends, marketing research of internal and external markets of products of light industry;

- create seasonal collections of clothes of different range of products, taking into account the national peculiarities and mentality of the population, development of technical specifications and descriptions of models, undertake research and consultancy activities;

- constant updating of the developed models taking into account market conditions, the creation of competitive fashion, providing interested organizations Advisory assistance in the development portfolio for their production, as well as employment in the textile, garment and knitting industry modern high-volume production processes;

- design and implementation based on the study of international experience, modern methods of cost accounting and ensuring profitability of products;

- organization of presentations of models of domestic and foreign clothing designers, conferences, exhibitions, seminars and master classes.

The strategic goal of the development of light industry - the creation of conditions for the intensification of its innovative development, ensure the effective compliance of production volumes, quality and range of products aggregate demand of consumers, increasing national importance of the industry and its image in the world community [3].

In order to improve the implementation of works on introduction of international quality standards, enforcement of certification and standardization, development of normative-technical documentation taking into account the development of international standards that ensure 
the harmonization of domestic and international industry standards, ISO-9001 implemented in 148 companies in the industry, there are certificates for all enterprises.

Today in Uzbekistan addressed the massive task of developing high-tech industries based on innovation. Significant amounts of innovative activity is carried out within the framework of approved state programs on modernization, technical and technological re-equipment of production.

In order to further the development of light industry of the Republic developed the "Program of development of textile and light industry of the Republic of Uzbekistan for the period 2010-2015”. Under this programme to bring the level within the Republican processing of cotton fiber up to $60 \%$ of the total volume produced in the Republic of fiber, to ensure the growth of industrial production by more than 3.2 times, to increase the export potential of more than 2.7 times, to meet consumer demand for high quality goods and create additional new jobs.

To date, light industry of the Republic and its administration has passed a long way of development. Were impressive results, and to adopt the necessary measures to increase the presence of products of light industry of the Republic of Uzbekistan on the world market. However, in the era of globalization of international relations created certain prerequisites and requirements for further improvement of the light industry of the Republic of Uzbekistan [4].

In recent years, the export by enterprises of SJSC "Uzbek light industry" has increased significantly, not only in volumes but also increased the number of countries and companies - exporters total exports increasing every year, for example, if in 2014 the share of new exporters was $4.2 \%$, while in 2015 this figure is expected to reach 6.0 percent, while the increase in total exports, compared $2014-1.3$ times.

To date, the main company's products for export is cotton yarn, melange yarn, compact yarn and dyed, woven fabrics of cotton and silk, knitted fabric harsh and ready, wide range of sewing and knitting and hosiery, as well as products made of silk. Every year new types of exported products, in 2013-2014 are, melange yarn, compact and dyed, Terry fabric, shirting, poplin, men and children's shirts, satin, baby diapers and labels, home textiles and ready-made clothes-jerseys new models and styles.

In addition to population, the complaint and the promotion of domestic brands to foreign markets, the company conducted market research and are accepted to participate in international trade fairs for the textile and fashion held abroad. For example, in 2012-2014 the industry successfully participated in exhibitions Korea
(Preview in Seoul), Turkey (TUYAP-2012), Spain (ITMA -2012), India (Tex Trends India 2012), Russian Federation (Federal international textile exhibition), Latvia (Fashion Textile) [5].

The company independently and in cooperation with the SJC "Uzbek light industry" is working on the development of the geography of exports, new markets, taking into account the demand for manufactured products in the global market.

The country has created a stable framework for economic activity, simplification of licensing procedures, business registration and certification of products, a large number of different benefits and privileges for joint ventures and foreign companies:

- the ability to buy for productive use cotton fiber at a discount in the amount of $15 \%$ of the value of cotton fiber, purchased at world prices, folding in accordance with quotations of index "A" and his Uzbek component, published in "Cotton Outlook" deferred for 90 days.

- exemption from payment of customs payments (except customs clearance fees) for imported equipment, components that are not produced in the Republic of raw materials used for production until January 1, 2016;

- the grace period for payment of customs payments (except customs clearance fees) for up to 60 days from the date of acceptance of customs Declaration in the production of textile goods, not included in the list approved by the Cabinet of Ministers of the Republic of Uzbekistan;

- permission to purchase for a freely-convertible currency (with charge VAT at the zero rate) textiles, finished products (yarn, fabric, knitted fabric and waste) in the domestic market at prices not below the world that prevailed at the time of conclusion of the contract, meaning that at least 80 percent of the products that are created from these semi-finished products will be exported;

- are exempted from payment of import customs duties imported for own use chemicals, colours, fittings and accessories, as well as other ancillary materials are not produced in the Republic;

- exemption from tax on property of enterprises of the textile industry, selling more than $80 \%$ of its products for SLE.

Conclusion: the Uzbek Light industry still has significant untapped investment potential, all the conditions for further accelerated growth. The main target of further work is to increase the production of goods for the domestic market, to meet the growing needs of the population. This requires: attraction investment in projects for the production of finished cotton fabrics, mixed 
fabrics, silk fabrics, sewing and knitted products, providing for the creation of mobile industries with mandatory formation in the composition of structures responsible for design, marketing, quick changeover of production taking into account the fashion and demand; the implementation of a permanent technical and technological re-equipment of existing and creation of new hightech industries; creation of conditions for increasing the level of processing of cotton fiber; increasing the export potential of the industry, creation of new work opportunities, improve the system of training and retraining; restoration of production of textile engineering.

\section{References:}

1. Thompson A.A., Strickland A.J. Green. Strategic management: concepts and situations, Transl. the $9^{\text {th }}$ eng. ed. - M.: Infra-M, 2001. - 412 p.

2. Yusupov S., Umarov G. Priority directions of development of light industry of Uzbekistan.//Etisalat VA-education. - Tashkent, 2011. - № 1. - P. 62-64.

3. Yusupov S. Methodological issues of strategy for development of textile enterprises.//Etisalat VA-education.Tashkent, 2011. - No. 3. - P. 77-81.

4. Yusupov S. Main ways of creating favourable conditions for the development of the textile industry.//International scientific-practical conference. - Tashkent, TITLI, 2007. - P. 161-165.

5. Yusupov S., Yusupov D. Problems in the development of the textile industry and their influence on the consumer market.//Proceedings of international scientific-practical conference. - Tashkent, TITLI, 2007. - P. 185-189.

6. Reports GAK “Uzbek light industry” for 2011-2014.

Yusupov Ulugbek, senior researcher

of the Department "Management"

of Tashkent State economic University"

E-mail:ulugbek_USA@bk.ru

\section{Industry characteristics management of innovative processes at the enterprises of light industry}

\footnotetext{
Abstract: this article considers the issues of innovative development and management of innovative processes in the knitting industry of Uzbekistan. Analyzed the main directions of innovative processes and provides recommendations for their management.

Keywords: innovation, knitwear industry, knitting machine, range, raw materials, quality, surface density fabric, bulk density fabric, the weave, the cost.

Introduction: Light industry of Uzbekistan has a long tradition in the processing of cotton fiber. Through Uzbekistan Great silk road, and goods by Uzbek craftsmen, especially fabrics were known in many countries of the world. Today, given the increasing global market demand for products made of natural fibers, light industry of Uzbekistan has unlimited possibilities in winning a leading position in the global market not only as a supplier of cotton fiber, but also as an exporter of textile products, especially ready jerseys.

Analysis: In addressing the needs of the population for consumer goods occupy a significant place in the knitting industry enterprises. Prospects of development of knitwear production in comparison with other industries is characterized by the following features:

- a wide range of knitted products, but also the substitutability of their, products made of fabric (for

example, stockings, gloves, sports apparel and others). Currently in our country is produced jerseys over 1500 assortments;

- opportunities meet the needs of the population elasticity, breathability, and others;

- ample opportunities during the knitting of knitting, to give the product a desired appearance and necessary properties;

- the possibility of using different textile raw materials: cotton, wool, staple fibers, natural and synthetic fibers, and chemical fibers;

- high level of technological development, compared with other branches of the textile industry;

- the highest level of technical and economic indicators of knitting production, in comparison with the weaving process [2].
} 